\title{
Pyrolysis Characteristics of Phoenix Dactylifera Date Palm Seeds Using Thermo-Gravimetric Analysis (TGA)
}

\author{
Mohammed Elamen Babiker, A. Rashid A. Aziz, Morgan Heikal, Suzana Yusup, and Mhadi Abakar
}

\begin{abstract}
Mass losses of Phoenix dactylifera date palm seeds (DPSs) were measured using a thermo-gravimetric analyzer (TGA). Six-milligram-sample of six varieties of DPSs were pyrolyzed in an inert condition (argon atmosphere) with a constant flow rate of $100 \mathrm{ml} / \mathrm{min}$ for the entire range of experiments. The experiments were conducted under non-isothermal conditions and at a heating rate of $20^{\circ} \mathrm{C} / \mathrm{min}$ until the furnace wall temperature reached $900^{\circ} \mathrm{C}$. The moisture (M), ash (ASH), volatile matter (VM) and fixed carbon (FC) of the selected date seeds were determined by means of proximate analysis. The weight percentages of carbon (C), hydrogen $(\mathrm{H})$, oxygen $(\mathrm{O})$, nitrogen $(\mathrm{N})$, sulfur $(\mathrm{S})$ and atomic ratios $(\mathrm{H} / \mathrm{C}$ and $\mathrm{O} / \mathrm{C})$ were determined through the ultimate analysis. The heating value, bulk and particle density of DPSs were also measured using a bomb calorimeter and ultra-pycnometer, respectively. The yield of the liquids was obtained by subtracting the total gaseous mass from the DTG data. The experiments demonstrated that there were significant differences in physiochemical properties of selected DPSs. The findings also revealed that DPSs contain much volatile compounds. DPSs energy densities were found to be among the high-quality biological feedstocks.
\end{abstract}

Index Terms-Date palm seeds, pyrolysis, TGA, thermal characteristic.

\section{INTRODUCTION}

Recently, the rise of concern about environmental protection, the energetic recovery of biomass via pyrolysis, gasification or combustion has gained greater attention in all over the world [1], [2]. Reference [3], reported that there are roughly 3,000 cultivars of DPSs in the world. DPSs are also classified, based on fruit characteristics such as flesh consistency and ripening time; or grouped into three categories, namely soft, semidry or dry depending on the texture of the fruit under normal ripening conditions [4]. Different equipment can be used to measure the pyrolysis products of biomass. Many researchers have used pyrolysis gas chromatography-mass spectroscopy to study the pyrolysis of cotton [5], pine wood [6], paper [7] and others [8], [9]. Moreover, thermogravimetry coupled with Fourier

Manuscript received April 4, 2013; revised June 4, 2013. This work was supported in part by Universiti Teknologi PETRONAS and the Green Technology MOR to the Centre for Automotive Research and Electric Mobility. Pyrolysis characteristics of Phoenix dactylifera date palm seeds using thermo-gravimetric analysis (TGA).

Mohammed Elamen Babiker, Rashid A. Aziz, Morgan Heikal, and Mhadi Abakar are with Automotive Research and Electric Mobility, Universiti Teknologi PETRONAS, Bandar Seri Iskandar Tronoh - 31750, Perak, Malaysia (e-mail: mohammedelamen@gmail.com)

Suzana Yusup is with Green Technology MOR, Universiti Teknologi PETRONAS, Bandar Seri Iskandar Tronoh - 31750, Perak, Malaysia.
Transform Infrared Spectroscopy were used successfully to determine products of pyrolysis [10], [11]. As the chemical conversion of solid raw materials to several products is highly reliant on the kinetic rates of the pyrolysis reactions, it is apparent that accurate kinetic models are required so as to design the efficient pyrolysis process [12]. Many studies on the pyrolysis of biomass wastes, such as kinetics and product analysis have been conducted [13]-[15]. However, there is hardly any study about date seeds pyrolysis and combustion characteristics [16], [17]. In this study, the thermal decomposition of pyrolyzed date seeds in an inert atmosphere with a constant flow rate, under non-isothermal conditions and at fixed heating rate of $20^{\circ} \mathrm{C} / \min$ up to $900^{\circ} \mathrm{C}$ was investigated. The model of non-isothermal kinetic method was used to interpret experimental data collected from the thermogravimetric analysis (TGA) and real-time gas analysis (GA). The current study was conducted to determine how DPSs feedstock would react to combustion process in a fluidized bed gasifier in order to conduct further investigations.

\section{EXPERIMENTAL PROCEDURES}

\section{A. Raw Material and Preparation}

Six types of DPSs cultivars were used in this analysis, namely Deglet Nour from Tunisia, Piarom from Iran, Safawi, Mabroom and Suffry from Saudi Arabia, and Aliya from Algeria. They were obtained from a local importer in Penang city, Malaysia. All samples were thoroughly cleaned with distilled water and exposed to direct sunlight. Seeds dehydration process was carried out in two successive days with the aim of reducing total moisture content to an absolute minimum. Then, the samples were prepared by crushing, grinding and sieving the date seeds using a plier, ordinary home-type blender and ASTM Round Test Sieves, respectively. Sieves mesh sizes were No. $60,250 \mu \mathrm{m}$ and No. $45,355 \mu \mathrm{m}$. Table I shows the types of date seed cultivars selected along with their physical and chemical properties.

\section{B. Characterization}

The proximate analysis was carried out based on the method described in the American Society for Testing Materials (ASTM) E870-82. The ultimate analysis was conducted using an elemental analyzer. The contents of carbon (ASTM E777), hydrogen (ASTM E777), nitrogen (ASTM E778), and sulphur (ASTM E775) was determined directly, while the oxygen content was calculated by 
difference (subtracting the $\mathrm{C}, \mathrm{H}, \mathrm{N}$ and $\mathrm{S}$ contents from $100 \%)$.

TABLE I: PHYSICAL AND CHEMICAL CHARACTERISTICS OF DATE SEEDS

\begin{tabular}{|c|c|c|c|c|}
\hline Samples & $\begin{array}{c}\text { Seed-fruit } \\
\text { weight } \\
\text { percentage } \\
(\%)\end{array}$ & $\begin{array}{c}\text { Bulk } \\
\text { density } \\
\left(\mathrm{kg} / \mathrm{m}^{3}\right)\end{array}$ & $\begin{array}{c}\text { Particle } \\
\text { density } \\
\left(\mathrm{kg} / \mathrm{m}^{3}\right)\end{array}$ & $\begin{array}{c}\text { Heating } \\
\text { value } \\
(\mathrm{kj} / \mathrm{kg})\end{array}$ \\
\hline Deglet Nour & 8.41 & 450 & 1451 & 18.548 \\
\hline Piarom & 10.50 & 630 & 1524 & 18.238 \\
\hline Safawi & 9.14 & 550 & 1511 & 18.226 \\
\hline Mabroom & 8.86 & 530 & 1521 & 18.362 \\
\hline Aliya & 12.56 & 730 & 1513 & 18.286 \\
\hline Suffry & 8.33 & 500 & 1445 & 18.440 \\
\hline
\end{tabular}

\section{Pyrolysis Experiments}

All TGA experiments were conducted under argon atmosphere with a determined purge flow rate of $100 \mathrm{ml} / \mathrm{min}$. A thermocouple was inserted into the reactor to monitor the wall temperature. At the beginning of each experiment, $6 \mathrm{mg}$ of the date seed sample was loaded into a sample pan in the heating zone of the TGA. Each sample was heated to $105-110^{\circ} \mathrm{C}$ over $10 \mathrm{~min}$ and maintained at $110^{\circ} \mathrm{C}$ with a hold up time of $30 \mathrm{~min}$ to obtain the weight loss percentage associated with moisture. After the drying process, the sample was heated to $900{ }^{\circ} \mathrm{C}$ for pyrolysis. Simultaneously, the gaseous compositions were measured during the biomass pyrolysis. At the start of each experiment, $45 \mathrm{~min}$ of $\mathrm{Ar}$ purging was applied. When the pyrolyzed products quit the reactor, tar and water were removed. The resultant weight loss of this step is the fixed carbon, while the remaining material after decomposition is the ash. The tar-free gas was additionally cleaned through the water trap system. Finally, the gas in the water trap system was measured by a real-time gas analyzer.

\section{RESUlT AND DiscUSSIONS}

\section{A. Date Seeds Physiochemical Properties}

Table I shows the results of physiochemical properties of date seeds varieties. Percentages of date seed to the total fruit weight were found to be varied significantly among seeds varieties except between Mabroom (8.86\%), Deglet Nour $(8.41 \%)$ and Suffry $(8.33 \%)$ varieties. However, Aliya variety had the highest percentage of seed weight (12.56\%), while Suffry variety showed the lowest percentage [18].

Storage and transportation of the biomass as a feedstock for gasification practice is a crucial due to pretreatment processes that require space and energy [19]. Moreover, the behavior of biomass during thermal decompositions shows how these materials would react against the controlled heating stages of the process.

In terms of bulk density measurement, Aliya exhibited the same trend as for weight percentage by having the highest value of bulk density $(730 \mathrm{~kg} / \mathrm{m} 3)$ compared to the lowest value obtained for Deglet Nour $(450 \mathrm{~kg} / \mathrm{m} 3)$. Moreover, there were no significant differences $(\mathrm{P}=0.05)$ between Safawi $(550 \mathrm{~kg} / \mathrm{m} 3)$ and Mabroom $(530 \mathrm{~kg} / \mathrm{m} 3)$ varieties. This character of Deglet Nour, i.e. low bulk density is considered as one of its disadvantages regarding energy density.
In contrast to bulk density, which was measured in an air medium to obtain the average density of the date seeds, particle density was conducted to measure the true density of solid seeds [20]. The results revealed that there were significant differences between varieties. However, Piarom was observed to have the highest density $(1524 \mathrm{~kg} / \mathrm{m} 3)$, while Suffry exhibited an opposite behavior by recording the lowest density of $1445 \mathrm{~kg} / \mathrm{m} 3$. Relatively large size and regular shape of Piarom variety compared to the other varieties could be the explanation of this phenomenon.

Concerning heating values, there were significant differences $(\mathrm{P}=0.05)$ among varieties except between Piarom, Safawi and Aliya. However, the lowest heating value (18.044 $\mathrm{kj} / \mathrm{kg}$ ) was recorded for Suffry, while the highest value $(18.548 \mathrm{kj} / \mathrm{kg})$ was obtained by Deglet Nour. These results indicate that heating values of date seeds are not in direct proportion to their corresponding density values. Moreover, the highest heating value of Deglet Nour is more than compensates for its low density.

\section{B. Date Seeds Thermal Analysis}

The results of changes in weight in relation to a temperature program of DPSs variety are shown in Fig. 1. Experiments conducted at temperatures range from 25 to $900^{\circ} \mathrm{C}$ at a heating rate of $20^{\circ} \mathrm{C} / \mathrm{min}$. (TG) and their first derivative (DTG) in a controlled inert atmosphere argon $(100 \mathrm{ml} / \mathrm{min})$ are also displayed. The results revealed that there were sudden drops in all DPSs varieties weight after $200{ }^{\circ} \mathrm{C}$. This finding could be attributed to the release of volatile matter and the beginning of decomposition and weight loss at this stage. However, the highest loss of date seeds weight occurred at $309^{\circ} \mathrm{C}, 308^{\circ} \mathrm{C}, 309^{\circ} \mathrm{C}, 306^{\circ} \mathrm{C}$, $307^{\circ} \mathrm{C}$ and $306^{\circ} \mathrm{C}$ for Deglet Nour, Piarom, Safawi, Mabroom, Aliya and Suffry respectively. Obviously, there were no significant differences between seeds varieties, and as such all varieties share the same behavior at this stage of pyrolysis. Moreover, it was noticed that all date seeds are pyrolyzed completely at $440^{\circ} \mathrm{C}$. After this temperature, there was a gradual drop in weight loss. This phenomenon could be explained by the decomposition process of remaining solid residues or char, which increased until $900{ }^{\circ} \mathrm{C}$. The unburned char were 17, 17, 23, 22, 17, and $16 \mathrm{wt} \%$ for Deglet Nour, Piarom, Safawi, Mabroom, Aliya and Suffry respectively.

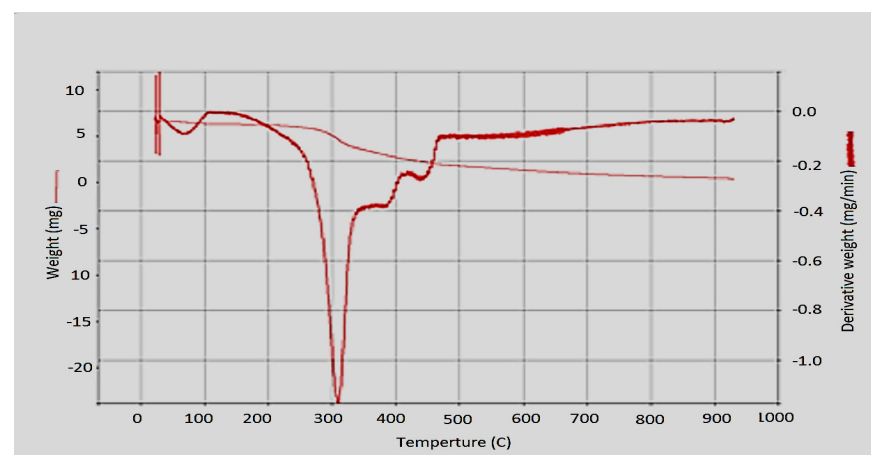

Fig. 1. Thermogravimetric and derivative Thermogravimetric profile of a date seed cultivar.

The proximate and ultimate analysis of date palm seeds on dry basis and values is given in Table II. Date seed is characterized as high volatile matter and low ash content. High volatility makes these biomasses technically feasible 
for combustion process in addition to bio-oil production from pyrolysis process.

TABLE II: Proximate And Ultimate AnAlysis: Weight Percentage

\begin{tabular}{|c|c|c|c|c|}
\hline Samples & Moisture & $\begin{array}{c}\text { Volatile } \\
\text { matter }\end{array}$ & Ash & Fixed carbon \\
\hline DegletNour & 4.5 & 80.1 & 10 & 5.4 \\
\hline Piarom & 4.1 & 78.1 & 9.8 & 8 \\
\hline Safawi & 4.3 & 75.7 & 11.5 & 8.5 \\
\hline Mabroom & 4.4 & 77.6 & 10.2 & 7.8 \\
\hline Aliya & 4 & 78 & 9.4 & 8.6 \\
\hline Suffry & 4 & 78.4 & 7.7 & 9.9 \\
\hline
\end{tabular}

\section{Date Seeds Lignocellulosic Components}

Lignocellulosic biomass is composed mainly of hemicellulose, cellulose and lignin. Generally, the main thermal decomposition of lignocellulosic materials occurs over the temperature range of $200-400{ }^{\circ} \mathrm{C}$ [21]. Hemicellulose also decomposes at the low temperature range between 160 and $360^{\circ} \mathrm{C}$, this could be attributed to the light weight of this component. The last component to decompose is cellulose, which occurs at high temperature range of 240 to $390^{\circ} \mathrm{C}$. Cellulose and hemicelluloses $\left(160\right.$ to $390{ }^{\circ} \mathrm{C}$ ) are highly reactive and decompose at low temperature compared to lignin. Lignin is characterize by a quite broad decomposition range of temperature $\left(250\right.$ to $\left.700^{\circ} \mathrm{C}\right)$ and could continue in the form of a long tail up to $900^{\circ} \mathrm{C}$. The existing of two major peaks observed in DTG curves may be qualitatively explained as follows: The first peak could be generated by the decomposition of hemicellulose and some of the lignin. The second peak should correspond to the decomposition of cellulose and the remaining lignin. At the temperatures above $400{ }^{\circ} \mathrm{C}$, the final decomposition involves the aromatization process of lignin fraction leading to very low weight loss. Typically, the thermochemical decomposition route followed by biomass is given as [22]; extractives, cellulose, hemicelluloses and finally lignin or char.

TABLE III: PeAK Temperature Related to Decomposition of Date SEEDS (C - Cellulose; H - HeMicellulose; L - Lignin)

\begin{tabular}{|c|c|c|c|}
\hline \multicolumn{4}{|c|}{ Pyrolysis temperature ${ }^{\circ} \mathrm{C}$} \\
\hline Samples & Peak 1 & Peak 2 & Peak 3 \\
\hline \multirow{2}{*}{ DegletNour } & $300-325$ & $375-400$ & $440-470$ \\
& $\mathrm{C}+\mathrm{H}+\mathrm{L}$ & $\mathrm{C}+\mathrm{L}$ & $\mathrm{L}$ \\
\hline \multirow{2}{*}{ Piarom } & $300-325$ & $380-405$ & $430-480$ \\
& $\mathrm{C}+\mathrm{H}+\mathrm{L}$ & $\mathrm{C}+\mathrm{L}$ & $\mathrm{L}$ \\
\hline \multirow{2}{*}{ Safawi } & $300-325$ & $360-420$ & $430-475$ \\
& $\mathrm{C}+\mathrm{H}+\mathrm{L}$ & $\mathrm{C}+\mathrm{L}$ & $\mathrm{L}$ \\
\hline \multirow{2}{*}{ Mabroom } & $300-325$ & $300-325$ & $300-325$ \\
& $\mathrm{C}+\mathrm{H}+\mathrm{L}$ & $\mathrm{C}+\mathrm{H}+\mathrm{L}$ & $\mathrm{C}+\mathrm{H}+\mathrm{L}$ \\
\hline \multirow{2}{*}{ Aliya } & $300-325$ & $360-410$ & $410-460$ \\
& $\mathrm{C}+\mathrm{H}+\mathrm{L}$ & $\mathrm{C}+\mathrm{L}$ & $\mathrm{L}$ \\
\hline \multirow{2}{*}{ Suffry } & $300-325$ & $360-410$ & - \\
& $\mathrm{C}+\mathrm{H}+\mathrm{L}$ & $\mathrm{C}+\mathrm{L}$ & - \\
\hline
\end{tabular}

These overlapping reaction mechanisms between lignocelluloses materials increase the complexity of the biomass reactions chemistry. In particular, the chemical composition of lignin varies inherently within the biomass materials and hence its reaction mechanism is still debated in the literature [23]. Accordingly, the temperature peaks from DTG curves related to degradation of date palm biomass and the lignocellulosic components is listed in Table III.

The first two peaks during pyrolysis process may be related to decomposition of cellulose, hemicelluloses and to some extent the lignin component. The degradation of lignin can be explained by peak 3 during decomposition process. However, the reactions for cellulose, hemicellulose and lignin may superimpose each other during reaction of peaks 1 , 2 and 3 and as such asserted similar view about decomposition of lignocellulosic materials. Two DTG peaks were observed for Deglet Nour; one initiated around $180^{\circ} \mathrm{C}$ and another at $500^{\circ} \mathrm{C}$. This shows that decomposition of lignin is quite unstable and difficult to predict.

\section{CONCLUSION}

In this work, six date palm seed samples from different regions were characterized and tested under inert atmosphere in TGA. Physiochemical and thermal characterizations of samples revealed that Aliyea, Piarom and Deglet Nour had the superiority in seed-fruit weight and bulk density, particle density and heating value respectively. Obtained high heating values and densities are satisfactorily fair to overcome the problems linked to low energetic density. Pyrolytic behavior of date palm seeds was studied by means of proximate and ultimate analysis as well as TGA. The findings revealed that date palm seeds contain much volatile compounds (75 to $83 \%$ ), low moisture content ( 4 to $5 \%$ ) and ash content ( 8 to $10 \%$ ) and as such they have the potential to be successfully utilized in combustion, torrefaction, pyrolysis, and gasification. Moreover, DPSs energy density were found to be among the high-quality biological feedstocks concerning energy recovery and recycling. The highest degree of reaction and conversion was established within the temperature range of 200 to $475^{\circ} \mathrm{C}$ for all selected cultivars. Regarding lignocellulosic components, there were no significant differences $(\mathrm{P}=0.05)$ among DPSs varieties. However, the main thermal decomposition of lignocellulosic materials generally occured over the temperature range of $200-400^{\circ} \mathrm{C}$.

\section{ACKNOWLEDGMENTS}

The authors would like to acknowledge the support given by Universiti Teknologi PETRONAS and the Green Technology MOR to the Centre for Automotive Research and Electric Mobility in performing this research.

\section{REFERENCES}

[1] C. Yin, L. A. Rosendahl, and S. K. Kær, "Grate-firing of biomass for heat and power production," Progress in Energy and Combustion Science, vol. 34, no. 6, pp. 725-754, 2008.

[2] J. Sandberg, C. Karlsson, and R. B. Fdhila, "A 7 year long measurement period investigating the correlation of corrosion, deposit and fuel in a biomass fired circulated fluidized bed boiler," Applied Energy, vol. 88, no. 1, pp. 99-110, Jan. 2011.

[3] S. M. Jain, J. M. Al-Khayri, and D. V. Johnson, Date Palm Biotechnology, pp. 206-208, Springer, 2011.

[4] M. A. Awad, "Increasing the rate of ripening of date palm fruit (Phoenix dactylifera L.) cv. Helali by preharvest and postharvest treatments," Postharvest Biology and Technology, vol. 43, no. 1, pp. 121-127, Jan. 2007.

[5] P. Zhu, S. Sui, B. Wang, K. Sun, and G. Sun, "A study of pyrolysis and pyrolysis products of flame-retardant cotton fabrics by DSC, 
TGA, and PY-GC-MS," Journal of Analytical and Applied Pyrolysis, vol. 71, no. 2, pp. 645-655, Jun. 2004.

[6] M. E. Arias, O. Polvillo, J. Rodríguez, M. Hernández, J. A. González-Pérez, and F. J. González-Vila, "Thermal transformations of pine wood components under pyrolysis/gas chromatography/mass spectrometry conditions," Journal of Analytical and Applied Pyrolysis, vol. 77, no. 1, pp. 63-67, Aug. 2006.

[7] D. Ibarra, J. C. del Río, A. Gutiérrez, I. M. Rodríguez, J. Romero, M. J. Martínez, and Á. T. Martínez, "Chemical characterization of residual lignins from eucalypt paper pulps," Journal of Analytical and Applied Pyrolysis, vol. 74, no. 1-2, pp. 116-122, Aug. 2005.

[8] W. T. Tsai, M. K. Lee, and Y. M. Chang, "Fast pyrolysis of rice straw, sugarcane bagasse and coconut shell in an induction-heating reactor," Journal of Analytical and Applied Pyrolysis, vol. 76, no. 1-2, pp. 230-237, Jun. 2006.

[9] M. F. Dignac, S. Houot, and S. Derenne, "How the polarity of the separation column may influence the characterization of compost organic matter by pyrolysis-GC/MS," Journal of Analytical and Applied Pyrolysis, vol. 75, no. 2, pp. 128-139, Mar. 2006.

[10] R. Bassilakis, R. Carangelo, and M. Wójtowicz, "TG-FTIR analysis of biomass pyrolysis," Fuel, vol. 80, no. 12, pp. 1765-1786, Oct. 2001.

[11] R. G. Saade and J. A. Koziński, "Numerical modeling and TGA/FTIR/GCMS investigation of fibrous residue combustion," Biomass and Bioenergy, vol. 18, no. 5, pp. 391-404, May 2000.

[12] T. Damartzis, D. Vamvuka, S. Sfakiotakis, and A. Zabaniotou, "Thermal degradation studies and kinetic modeling of cardoon (Cynara cardunculus) pyrolysis using thermogravimetric analysis (TGA)," Bioresource technology, pp. 6230-6238, 2011.

[13] M. Becidan, Ø. Skreiberg, and J. E. Hustad, "Experimental study on pyrolysis of thermally thick biomass residues samples: Intra-sample temperature distribution and effect of sample weight ('scaling effect')," Fuel, vol. 86, no. 17-18, pp. 2754-2760, Dec. 2007.

[14] R. A. Khalil, E. Mészáros, M. G. Grønli, G. Várhegyi, I. Mohai, B. Marosvölgyi, and J. E. Hustad, "Thermal analysis of energy crops: Part I: The applicability of a macro-thermobalance for biomass studies," Journal of Analytical and Applied Pyrolysis, vol. 81, no. 1, pp. 52-59, Jan. 2008

[15] A. Skreiberg, Ø. Skreiberg, J. Sandquist, and L. Sørum, "TGA and macro-TGA characterisation of biomass fuels and fuel mixtures," Fuel, vol. 90, no. 6, pp. 2182-2197, Jun. 2011.

[16] H. H. Sait, A. Hussain, A. A. Salema, and F. N. Ani, "Pyrolysis and combustion kinetics of date palm biomass using thermogravimetric analysis," Bioresource Technology, vol. 118, no. 0, pp. 382-389, Aug. 2012

[17] Y. El may, M. Jeguirim, S. Dorge, G. Trouvé, and R. Said, "Study on the thermal behavior of different date palm residues: Characterization and devolatilization kinetics under inert and oxidative atmospheres," Energy, vol. 44, no. 1, pp. 702-709, Aug. 2012.

[18] W. H. Barreveld, "By-products of date packing and processing," Date palm products. Rome, Italy, Series V. no. 101, Food and Agriculture Organization of the United Nations, sec. 4.2, pp. 170-174, 1993.

[19] R. P. Anex, A. Aden, F. K. Kazi, J. Fortman, R. M. Swanson, M. M. Wright, J. A. Satrio, R. C. Brown, D. E. Daugaard, A. Platon, G. Kothandaraman, D. D. Hsu, and A. Dutta, "Techno-economic comparison of biomass-to-transportation fuels via pyrolysis, gasification, and biochemical pathways," Fuel, vol. 89, Supplement 1, no. 0, pp. S29-S35, Nov. 2010.
[20] M. R. Wu, D. L. Schott, and G. Lodewijks, "Physical properties of solid biomass," Biomass and Bioenergy, vol. 35, no. 5, pp. 2093-2105, May 2011.

[21] M. Carrier, A. Loppinet-Serani, D. Denux, J. M. Lasnier, F. Ham-Pichavant, F. Cansell, and C. Aymonier, "Thermogravimetric analysis as a new method to determine the lignocellulosic composition of biomass," Biomass and Bioenergy, vol. 35, no. 1, pp. 298-307, Jan. 2011.

[22] A. N. Shebani, A. J. van Reenen, and M. Meincken, "The effect of wood extractives on the thermal stability of different wood-LLDPE composites," Thermochimica Acta, vol. 481, no. 1-2, pp. 52-56, Jan. 2009.

[23] G. Jiang, D. J. Nowakowski, and A. V. Bridgwater, "A systematic study of the kinetics of lignin pyrolysis," Thermochimica Acta, vol. 498, no. 1-2, pp. 61-66, Jan. 2010.

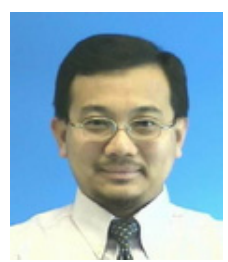

Mohammed Elamen Babiker is a $\mathrm{PhD}$ candidate at Automotive Research and Electric Mobility, Mechanical Department, Universiti Teknologi PETRONAS, Malaysia. He obtained his bachelor's and master's degrees from Department of Agricultural Engineering, University of Gezira, Sudan. He currently works for University of Gezira as lecturer. His present research focuses on usingDate palm wastes as a source of fuel in ICE.

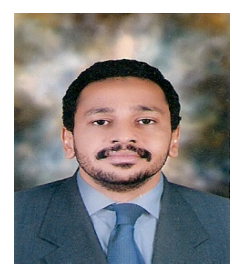

A. Rashid A. Aziz is an associate professor at Automotive Research and Electric Mobility, Mechanical Department, Universiti Teknologi PETRONAS, Malaysia. He earned his PhD, MSc and BSc from University of Miami, Florida. He is specialized in Internal Combustion Engine, Combustion and Laser Diagnostics, Flow visualization, Computational Fluid Dynamics, Hybrid Powertrain. Modeling, design, modification and test of combustion and fuel system of two-stroke free piston linear generator engine.

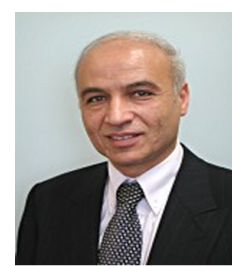

Morgan Heikal is a senior professor at Automotive Research and Electric Mobility, Mechanical Department, Universiti Teknologi PETRONAS, Malaysia. He also works as Head of the Centre for Automotive Engineering, Ricardo Professor of Automotive Engineering, Head of Engineeringa Research Centre etc.

His recent research concentrates on IC Engines, Laser diagnostic techniques and Compact heat exchangers.

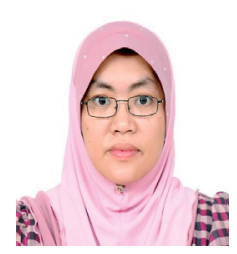

Suzana Yusup is associate professor at chemical department and heads Green Technology MOR, Universiti Teknologi PETRONAS, Perak, Malaysia. She obtained her PhD (Chemical Engineering: Powder Technology) from University of Bradford, MSc (Chemical Engineering: Adsorption) from University of Wales, BEng (Chemical Engineering) from University of Leeds. Dr Yusup has a special interest in Biomass Utilization / Biofuel Production Research. 